

\section{Kunnskapsbasert praksis i sykepleierutdanningen}

Forfattere: Torunn Erichsen, Gro

Røkholt og Inger Utne

\section{NøKKELORD}

- Kunnskapsbasert praksis

- Sykepleierutdanningen

- Litteraturgjennomgang

\section{INNLEDNING}

Pasientsikkerhet og kvalitet er prioriterte område i helsetjenesten $(1,2)$ og man forventer at oppdatert kunnskap ligger til grunn for beslutninger i klinisk praksis (1). Ifølge HelseOmsorg21 svarer dagens utdanninger $\mathrm{i}$ for liten grad til de utfordringer helsevesenet står overfor på dette feltet (3).

A utøve kunnskapsbasert praksis (KBP) innebærer å ta faglige avgjørelser basert på systematisk innhentet forskningsbasert kunnskap, erfaringsbasert kunnskap og pasienters ønsker og behov i den gitte situasjon (4, 5). For å jobbe kunnskapsbasert, må sykepleiere ha kompetanse $\mathrm{i}$ faglig refleksjon, formulering av kliniske spørsmål, gjennomføring av søk, kritisk vurdering av forskningslitteratur samt anvendelse og presentasjon av forskning (4).

Internasjonale studier viser at sykepleiere $\mathrm{i}$ praksisfeltet mangler grunnleggende kunnskaper i $\operatorname{KBP}(6,7)$ og at mange sykepleiere i praksis er negative til å anvende forskning $(8,9)$. I en litteraturgjennomgang fra 2011 ble det påpekt at tiltak mot kartlagte barrierer, kompetanseoppbygging og fagutvikling har betydning for å fremme kunnskapsbasert praksis (10).

Det foreligger helsepolitiske foringer om at utdanningsmiljøene skal integrere kunnskapsbaserte arbeidsformer i profesjonsutdanningene $(3,11)$. Internasjonalt tas det til ordet for at KBP må integreres i programplaner i helsefagutdanningene $(5,12)$ og i medisinerutdanningene $(13,14)$. Til tross for økt oppmerksomhet om KBP, vet vi lite om hvordan dette er implementert i sykepleierutdanningene. En norsk studie undersøkte sykepleiestudentenes erfaringer med implementering av KBP i praksisstudiene. Resultatet av den antyder at det kan foreligge kulturelle utfordringer mellom studentenes læringsmål og anvendelse av KBP i praksis (9). En svensk studie (15) viste at det var store forskjeller i hvordan studentene fra forskjellige universiteter i Sverige opplevde at KBP var vektlagt i sykepleierutdanningene.

I Norge ble det uteksaminert 3630 sykepleiere i 2014 (16). Nyutdannete sykepleiere utgjør en stor gruppe og vil dermed ha en sentral rolle i å arbeide kunnskapsbasert. Her har utdanningsinstitusjonene et stort ansvar. Fra helsepolitisk hold foreslås obligatorisk opplæring i kunnskapshåndtering og kunnskapsbasert praksis for alle helsefagutdanningene (3). Dersom helsepolitiske mål om kunnskapsbaserte helsetjenester skal nås, må studentene oppnå tilstrekkelig kompetanse om KBP i løpet av utdanningen. Hensikten med denne litteraturgjennomgangen er derfor å identifisere og beskrive forskning om KBP i sykepleierutdanningen.

\section{METODE}

Litteraturgjennomgangen er en modifisert scoping review basert på rammeverket til Arksey og O’Malley (17). Scoping review

\section{Hva tilfører artikkelen?}

Studien antyder at systematiske undervisningsopplegg i kunnskapsbasert praksis gjennom hele utdanningen har positiv innvirkning på studentenes læring.

\section{Mer om forfatterne:}

Torunn Erichsen er førstelektor HiOA. Gro Røkholt er høgskolelektor og faglig ansvarlig for videreutdanning i kunnskapsbasert praksis, HiOA. Inger Utne er førsteamanuensis ved HiOA. Kontaktperson: torunn.erichsend hioa.no 


\begin{tabular}{lccc}
\hline \multicolumn{2}{l}{ Tabell 1: Oversikt over antall treff, relevante og inkluderte artikler } \\
\hline $\begin{array}{l}\text { Database } \\
\begin{array}{l}\text { Cochrane Libary } \\
\text { - Cochrane } \\
\text { Reviews }\end{array}\end{array}$ & Relevante & Inkluderte \\
- Other Reviews & 9 & 0 & 0 \\
Embase & 3 & 0 & 0 \\
Medline & 96 & 2 & 0 \\
Cinahl & 185 & 25 & 6 \\
Eric & 20 & 24 & 3 \\
Swemed + & 70 & 3 & 0 \\
Hånds $\varnothing k$ & & 1 & 1 \\
\hline
\end{tabular}

er benyttet fordi det er en egnet metode for å få oversikt over et forskningsfelt der ulike studiedesign benyttes. Sammenliknet med en systematisk litteraturstudie åpner scoping review for inklusjon av ulike studiedesign (17). Scoping review er valgt som metode fordi forskningsfeltet er begrenset og vi ønsket å inkludere alle relevante artikler. For å sikre god kvalitet i søkeprosessen ble søket planlagt og gjennomført i samarbeid med bibliotekar. Det ble søkt i databasene Cochrane Library, Medline, Cinahl, Embase, Swemed+ og Eric, i perioden fra 1. januar 2000 til 15. desember 2014. Søkene ble begrenset til fag-

schools, health occupations/(or schools, nursing/ or universities/ or education, nursing/ or education, nursing, baccalaureate/ or education, nursing, graduate/ or nursing education research/) and curriculum/ (or faculty, nursing/ or learning). Vi gjennomførte kombinasjonssøk med de samme emneordene som ble tilpasset de ulike databasene. I Medline la vi til «facilitat*" og «implement** for å spisse treffene. Nordiske tidsskrifter er ikke automatisk indeksert i Cinhal og Medline. Det ble derfor søkt i Swemed+ med søkeordene evidence based og nursing education. For de periodene tidsskrift ene ikke forelå online, ble det

\section{Mange sykepleiere i praksis er negative å anvende forskning.}

fellevurderte publikasjoner på engelsk eller skandinavisk språk.

Følgende emneordene ble kombinert; evidence-based practice/(or evidence based or evidence-based or evidencebased or research based or research-based or researchbased or knowledge based, or knowledge-based or knowledgebased) and nursing/ (or evidence-based nursing/) and knyttet til KBP i sykepleierutdanningen. Kun studier fra bachelornivå i sykepleie ble inkludert. Studier fra videreutdanninger, masterutdanninger og kommentarartikler ble ikke inkludert.

\section{RESULTATER}

Tabell 1 viser en oversikt over antall treff, databaser og inkluderte studier. En totrinnsprosess ble benyttet for å gjennomgå treff og utvelgelse av relevante artikler (18). To av forfatterne leste tittel og abstrakt på samtlige treff (386). Trehundreogtrettien artikler ble ekskludert $i$ henhold til inklusjons- og eksklusjonskriterier. Den andre delen av prosessen besto av en grundig gjennomlesning av de resterende artiklene (55). To forfattere leste samtlige i fulltekst med tanke på endelig inklusjon ut fra kriteriene. Uoverensstemmelser mellom to av forfatterne ble løst ved diskusjon.

Det ble inkludert elleve studier, hvorav ni fra USA, en fra Italia og en fra Kina. Studiene belyste ulike typer av spørsmål og hadde varierende kvalitet. Forskningsdesignene varierte fra en litteraturgjennomgang (19), to kvasieksperimentelle studier $(20,21)$, en artikkel med aksjonsforskningsdesign (22) en kohortstudie (23), to beskrivende $(24,25)$ og fire casestudier (26-29). Casestudiene, aksjonsforskningsstudiet og en av de beskrivende studiene (25) omhandlet organisering og læringsaktiviteter om KBP i utdanningen og gir innsikt i hvordan dette kan ha positiv innvirkning på enkeltstudenters læring. De kvasieksperimentelle studiene $(20,21)$, en beskrivende studie (24) og kohortstudien (21) viser effekt av læringsaktiviteter om KBP for grupper av studenter. Tabell 2 viser en oversikt over de inkluderte studiene. 
Tabell 2: Oversikt over inkluderte studier

\begin{tabular}{|c|c|c|c|c|}
\hline $\begin{array}{l}\text { Studie } \\
\text { (Forfatter, } \\
\text { utgivelsesår, } \\
\text { land ref.nr.) }\end{array}$ & Hensikt & $\begin{array}{l}\text { Studi- } \\
\text { edesign og } \\
\text { metode }\end{array}$ & Utvalg & Målemetode \\
\hline $\begin{array}{l}\text { Finotto, m.fl., } \\
\text { (2013) } \\
\text { Italia (24) }\end{array}$ & $\begin{array}{l}\text { Beskrive nyutdan- } \\
\text { nede sykepleieres } \\
\text { oppfatninger om } \\
\text { hva de har lært om } \\
\text { KBP. }\end{array}$ & $\begin{array}{l}\text { Beskri- } \\
\text { vende }\end{array}$ & $\begin{array}{l}\text { Ny- } \\
\text { utdannede } \\
\text { syke- } \\
\text { pleiere. } \\
(\mathrm{N}=300) .\end{array}$ & $\begin{array}{l}\text { Egenutviklet spør- } \\
\text { reskjema om bruk } \\
\text { og nytteverdi av KBP } \\
\text { relatert til bachelo- } \\
\text { roppgave, klinisk } \\
\text { praksis og fremtidig } \\
\text { yrkesutøvelse. }\end{array}$ \\
\hline
\end{tabular}

Zhang m.fl., Evaluere effekt av (2011) ny undervisningsKina (21) strategi om KBP.

Moch, Cronje \& Bradson, (2010)

USA

(19)
Gi en oversikt over omfang og innhold $i$ undervisning om KBP i bachelor i sykepleie.
Kvasieksp- Studenter erimentelt, fra syv pre-og universitet posttest. $\quad(\mathrm{N}=75)$
Egenutviklet spørreskjema med utfallsmål om kunnskaper, holdninger og atferd om KBP.

Litteratur- 62 refegjennom- ranser gang $\quad$ (8 bøker og 54 artikler).
Moch \& Cronje, (2010) USA (22)
Beskrive og prøve Aksjonsut en læringsmodell forskning for å fremme KBP.
Studenter og sykepleiere.
Prosessoppsummeringer og spørreskjema med åpne spørsmål.

\section{Resultat}

Et gjennomgående program i KBP over 3 år fremmet studentens ferdigheter i bruk av KBP. Lærers veilederrolle i KBP ble vurdert positivt.

Praksisveileders rolle i å stimulere til bruk av KBP for å løse kliniske sykepleieproblemer fikk lavere score.

Vanskelig å formulere kliniske spørsmål.

Sannsynligvis ville de anvende KBP i praksis.

Signifikant bedring i studentens kunnskap, holdninger og atferd om KBP.

Noe forbedringer når det gjaldt analytiske evner, selvstendig læring, samarbeidsevner, forståelsen av KBP og evne til å lese forskningslitteratur. De fleste oppga at de ville ta aktiv del i videre læring og implementering av KBP. Læringsutbyttet på selvstudie om KBP ble vurdert moderat, og studentene etterspurte mer veiledning. Workshop med kritisk vurdering av forskningsartikler ble godt vurdert.

Alle trinnene i KBP måtte inngå i programplanen. Ikke tilstrekkelig med bare forelesninger om KBP for at læring skulle finne sted. Studentaktive metoder som stimulerte studentenes evne til kritisk tenkning ble trukket frem som sentralt. Betydningen av et forpliktende samarbeid mellom utdanning og praksisfelt ble fremhevet. Når studentene fikk mulighet til å anvende KBP knyttet til relevante kliniske problemstillinger, så det ut til å ha positiv betydning for læringsprosessen.

Prosessoppsummeringer viste at både studenter og sykepleiere i praksis var fornøyd med deltagelsen i kunnskapsgruppene. Det stimulerte til refleksjon og $\varnothing k t$ faglig engasjement i praksis. Kunnskapsgruppene hadde bidratt til bedret kommunikasjon mellom ansatte og studenter og økt interessen for forskning i praksisfeltet.

Sykepleierne beskrev at de så på studentene som ressurser og bidragsytere for å finne aktuell litteratur knyttet til kliniske problemstillinger. 
Tabell 2 fortsetter her:

\begin{tabular}{ll}
\hline $\begin{array}{l}\text { Studie } \\
\text { (Forfatter, }\end{array}$ & Hensikt \\
utgivelsesår, & \\
land ref.nr.) & \\
Kim m.fl., & Evaluere \\
(2009) & effekt av et interak- \\
USA & tivt under-visnings- \\
(20) & opplegg i KBP. \\
& \\
& \\
& \\
Krus-zewski, & Undersøke om \\
Brough \& & endring i program- \\
Killeen, & planen gir $ø$ kt \\
(2009) & kompetanse i KBP. \\
USA & \\
(23) &
\end{tabular}

$\begin{array}{lll}\begin{array}{l}\text { Studi- } \\ \text { edesign og } \\ \text { metode }\end{array} & \text { Utvalg } & \text { Målemetode } \\ & & \\ \text { Kvasieksp- } & \text { Studenter i } & \text { Spørreskjema om } \\ \text { erimentelt, } & \text { 3. studieår. } & \text { kunnskaper, hold- } \\ \text { pre-og } & \text { Ekspr.gr. } & \text { ninger og ferdigheter } \\ \text { posttest } & \text { (N=88). } & \text { i KBP. } \\ \text { medkon- } & \text { Kontrollgr. } & \\ \text { troll- } & (\mathrm{N}=120) . & \\ \text { gruppe. } & & \\ & & \end{array}$

\section{Kohort}

Studenter $(\mathrm{N}=24)$ og praksisveiledere.

\section{Ross, m.fl., (2009) \\ USA}

(27)

Schmidt

\& Brown

(2007)

USA

(28)
Beskrive

undervisning-

opplegg i KBP.

Beskrive en undervisnings strategi for å fremme KBP.
Casestudie

Casestudie

Studenter, lærere og praksisveiledere.
Standardisert spørreskjema med utfallsmål om kunnskaper, ferdigheter og forståelse for bruk KBP. Skriftlig/muntlig programevaluering. Semistrukturert fokusgruppeintervju med praksisveiledere.

Tilbakemelding om undervisningsstrategien fra studenter, lærere og praksisfelt.

\section{Resultat}

Gruppen som fikk et interaktive undervisningsopplegg scoret signifikant bedre på kunnskaper om og anvendelse av KBP enn gruppen som fikk standardundervisning. Det var ingen signifikant forskjell mellom gruppene på holdninger til KBP og tanker om fremtidig bruk av KBP.

Studentene scoret høyt på kunnskap om og forståelse for bruk av KBP og på tro på betydningen av metoden for kvalitet i praksis. Studentene vurderte egen kompetanse i å identifisere et problemområde som god. Spørsmål som fikk lavere score var evnen til kritisk vurdering av forskning og til å identifisere elementene i implementering av ny kunnskap i praksis. Studentene vurderte det å arbeide med KBP i samarbeide med praksisfeltet som positivt. Praksisveilederne var fornøyd med studentenes kunnskaper og ferdigheter i KBP. De beskrev at prosjektet ga større ansvar og nærhet til studentenes læringsprosess. De fremhevet at utbyttet for praksisfeltet var stort når det gjaldt å få tilført ny kunnskap relatert til kliniske problemstillinger.

Ny fagplan der KBP ble innført som et gjennomgående emne over tre år. Det er beskrevet detaljerte læringsaktiviteter og innhold med stigende progresjon gjennom tre år.

Studentene vurderte det å arbeide med praksisnær problemstillinger som lærerikt.

Pris for beste poster ble vurdert som morsomt og stimulerende. Studentene rapporterte frustrasjon over gruppekonflikter. Lærerne vurderte modellen som gunstig for studentenes læring om ledelse, kritisk tenkning og kommunikasjon. De vurderte studentenes presentasjoner til å være meget gode. Undervisningen fremmet samarbeidet mellom student og lærer. Studentenes arbeidsmengden ble vurdert som realistisk.

Praksisfeltet oppga nytteverdi av studentenes fremlegg for å løse kliniske problemstillinger. Utfordringen var mangel på tid for å vurdere kvalitet og innføring av de forslåtte endringene. 
Tabell 2 fortsetter her:

$\begin{array}{ll}\begin{array}{l}\text { Studie } \\ \text { (Forfatter, } \\ \text { utgivelsesår, } \\ \text { land ref.nr.) }\end{array} & \text { Hensikt } \\ \text { Brancato, } & \text { Beskrive og prøve } \\ \text { (2006) } & \text { ut en ny lærings- } \\ \text { USA } & \text { modell i praksis- } \\ \text { (29) } & \text { studier. }\end{array}$

$\begin{array}{lll}\begin{array}{l}\text { Studi- } \\ \text { edesign og } \\ \text { metode }\end{array} & \text { Utvalg } & \text { Målemetode } \\ \text { Casestudie } & \begin{array}{l}\text { Studenter, } \\ \text { lærere og } \\ \text { praksis- } \\ \text { veiledere. }\end{array} & \begin{array}{l}\text { Skriftlig og muntlig } \\ \text { evaluering fra alle } \\ \text { involverte. }\end{array} \\ & \end{array}$

\section{Resultat}

Studentene rapporterte $ø \mathrm{kt}$ forståelse for KBP. De så betydningen av å stille spørsmål til praksis og de hadde fått økt innsikt i hvordan KBP kunne bidra til forbedringer i pasientbehandlingen.

Prosjektet førte til at lærere ble utfordret til å integrere KBP som læringsmetode i programplanen. De anså metoden som egnet for å bygge bro mellom utdanning og praksisfelt. Ansatte i praksisfeltet rapporterte at prosjektet hadde ført til økt oppmerksomhet på forskning og KBP i avdelingen.

Killeen \&

Barnfather, (2005)

USA

(26)

Klem \&

Weiss, (2005)

USA

(25)
Beskrive undervisnings-strategi for å implementere KBP i sykepleieutdanningen.
Casestudie Studenter i 3. studieår.

Gradert vurdering av læringsutbytte etter fastlagte kriterier.

Studentene fikk gjennomgående bedre karakterer på presentasjoner i praksis både på innhold og gjennomføring enn før ny emneplan trådte i kraft. Praksisfeltet rapporterte at studentarbeidene hadde bidratt til kvalitetsforbedring på konkrete prosjekter i praksis.

Prosjektsamarbeidet bidro til $\emptyset k t$ rekruttering av nyutdannede sykepleiere til disse praksisstedene.

Betydningen av samarbeid med bibliotekar for å planlegge og gjennomføre undervisning om KBP ble vektlagt. Det ble beskrevet hvordan kunnskapsbaserte søk kan utføres og arbeid med kritisk vurdering ble utdypet spesielt. Det ble fremhevet at samarbeid med bibliotekar kunne styrke utdanningene i utvikling av planverk og $\mathrm{i}$ undervisning og veiledning av studenter. 


\section{Struktur og innhold i program- planen}

Samtlige artikler beskrev at læringsaktiviteter i alle trinnene i KBP måtte inngå i programplanen.

Tabell 3 viser en oversikt over studentenes læringsaktiviteter i de inkluderte studiene. Tre studier $(22,24,27)$ beskrev undervisningsopplegg gjennom alle tre år, mens fem studier $(20,21,26,28,29)$ hadde konsentrert læringsaktivitetene mot slutten av utdanningen. I de fleste oppga studentene at studieopplegget hadde gitt økt innsikt i og forståelse for forskning, spesielt gjennom arbeid med bacheloroppgaven. I første studieår jobbet studentene teoretisk med å beskrive hensikten med KBP og hvordan man skulle gå frem for å jobbe kunnskapsbasert. I påfølgende praksisperiode arbeidet studentene med å formulere kliniske spørsmål og sette opp PICO. I andre studieår gjennomførte studentene søk og kritisk vurdering, mens i tredje år

\section{KBP fordrer et ulikt sett av ferdigheter som studentene trenger tid for å lære.}

artiklene var KBP inkludert i kliniske emner i programplanen $(20-24,26,27,29)$ hvorav tre knyttet til emnet ledelse $(20,26,27)$.

I samarbeid med praksisfeltet utviklet Moch, \& Cronje (22) en ny studiemodell der undervisningsopplegget om KBP var gjennomgående i tre år. Praksiskonteksten var sentral både $\mathrm{i}$ utvikling og gjennomføring av modellen. Studentene arbeidet blant annet med forskningsartikler i kunnskapsgrupper, på tvers av utdanningsnivåer, sammen med lærer og ansatte i praksisfeltet. Studentenes rolle endret seg fra å være observatører i starten til å bli ledere av kunnskapsgruppene mot slutten av studiet. I kunnskapsgruppene ble artikler om temaer fra praksisfeltet diskutert og kritisk vurdert. Studentene søkte aktuell forskning, utarbeidet kunnskapsoppsummeringer og la plan for implementering.

Finotto og kollegaer (24) rapporterte signifikant bedring i studentenes ferdigheter i KBP, etter at KBP var implementert $\mathrm{i}$ programplanen, med progresjon gjennom alle tre årene. Videre var søkestrategi i ulike databaser og forskjellige studiedesign vektlagt. Studentaktive metoder hvor studentene arbeidet i grupper var også vektlagt.

Hvor grundig læringsaktivitetene ble beskrevet varierte i de inkluderte studiene. De fleste kombinerte forelesninger og/eller e-læring med påfølgende oppgaveløsning (20-24,26-29). En studie (20) undersøkte effekten av et interaktivt undervisningsopplegg i KBP over ett semester mot slutten av utdanningen. Intervensjonen, også kalt E-FIT, besto av to timers introduksjon i KBP med påfølgende gruppeoppgave $\mathrm{i}$ praksis. Gruppeoppgaven inkluderte problemidentifikasjon, litteratursyntese, implementeringsstrategi og fremlegg. Resultatene viste signifikant effekt på studentens kunnskap om KBP for intervensjonsgruppen, men ingen forskjell mellom gruppene på holdninger og fremtidig bruk av KBP (20).

Etter innføring av en todelt intervensjon gjennomførte Zhang og kollegaer (21) et kvasieksperimentelt studie med deltakere fra sju universiteter. I fase 1 jobbet studentene individuelt med et e-læringskurs om KBP og gjennomførte et litteratursøk (se tabell 3). Fasen ble avsluttet med en gruppebasert studierapport der studentene beskrev hvordan de forsto KBP, hvilken betydning KBP har for sykepleievitenskapen og et praktisk eksempel der de anvendt trinnene i KBP. I fase 2 jobbet gruppene med kritisk vurdering av utvalgte forskningsartikler. Hver gruppe fikk tildelt en artikkel de skulle diskutere relatert til forskningsspørsmålet, litteraturgjennomgangen og et teoretisk rammeverk. Videre skulle gruppene reflektere over og vurdere metodiske aspekter ved artikkelen relatert til forskningsdesign, utvalg, datainnsamling metode og analyse. Det ble arrangert tre gruppemøter hvor studentene delte sine vurderinger. Studenter i samme gruppe hadde arbeidet med den samme artikkelen. Lærer og praksisveileder veiledet gruppene og studentene kom frem til en konsensus om styrker og svakheter ved artikkelen. Studien viste signifikant effekt på studentenes kunnskaper om KBP, holdninger og atferd. Videre ble det rapportert om signifikante forbedringer i analytisk evne, problemløsning, evne til å arbeide selvstendig og i samarbeid med andre. Fase 1 med selvstudie fikk lavere skåre enn fase 2 som var veiledet av lærer og praksisveileder.

Gruppearbeid Åtte artikler (20-24, 26-28) beskrev at studentene arbeidet i grupper hvorav seks beskrev en gruppestørrelse fra fire til seks deltakere (20-23, 26,28). En av artiklene beskrev gruppesammensetning på tvers av emner og nivåer (22).

Studieoppgaver Studieoppgavene varierte i antall og omfang. Noen var omfattende og detaljert beskrevet $(20,23,24,26-29)$ og noen hadde klare læringsut- 
Tabell 3: Studentenes læringsaktiviteter i inkluderte studier

\section{(Forfatter, utgi- velsesår, land ref.nr.)}

Finotto, m.fl., (2013), Italia (24)

Zhang m.fl., (2011), Kina (21)

Moch, Cronje \& Bradson, (2010). USA(19)

Moch \& Cronje, (2010), USA (22)

Kim m.fl., (2009) USA (20)

Kruszewski, Brough \& Killeen, (2009), USA (23)

Ross, m.fl., (2009), USA (27)

Schmidt \& Brown, (2007). USA (28)

Brancato, (2006), USA (29)

Killeen \& Barnfather, (2005), USA (26)

Klem \& Weiss, (2005), USA (25)
Studentene gjennomførte læringsaktiviteter ut i fra detaljerte læringsutbyttebeskrivelser i programplanen.Studentene startet med spørsmålsformulering. PICO, litteratursøk i ulike databaser og kritisk vurdering. Studentene anvendte KBP i bacheloroppgaven og praksis. Tidsramme: Progresjon over tre år.

Studentene gjennomførte et e-læringskurs om KBP med påfølgende individuelt litteratursøk. Deretter delte de erfaringene i gruppe og utarbeidet en felles grupperapport der de beskrev betydningen av forskningsbasert kunnskap og egen forståelse av KBP. I praksis deltok studentene i workshops. Her ble tre utvalgte forskningsartikler kritisk vurdert i grupper. Flere grupper vurderte de samme artiklene og presenterte resultatene for hverandre. Studentene fikk veiledning av sykepleieforsker og praksisveileder. Tidramme: Ett semester mot slutten av utdanningen.

Oversiktsartikkel. Studentaktive metoder som stimulerer studentenes evne til kritisk tenkning trekkes frem som sentralt. Alle trinnene i KBP må inngå i programplanen.

Studentene deltok i kunnskapsgrupper sammen med sykepleiere fra praksisfeltet og lærer. Sykepleiere fra praksis valgte tema og studentene gjennomførte litteratursøk. I felleskap ble svakheter og styrker ved artiklene diskutert. Studentene arbeidet med KBP på ulike måter gjennom hele utdanningen. Det ble inngått kontrakter mellom studenter og praksisfelt som beskrev studentenes forpliktelser i konkrete KBP prosjekter. Tidsramme: Progresjon over tre år.

Etter en introduksjon om KBP deltok studentene i et gruppebasert praksisprosjekt. Studentene utarbeidet en klinisk problemstilling i samarbeid med praksisfeltet. Deretter gjennomførte studentene litteratursøk med PICO, kritisk vurdering, kunnskapsoppsummering og utarbeidet en implementeringsplan for praksis. Fremlegg (Power-Point og Poster).Tidsramme: Ett semester mot slutten av utdanningen.

Studentene gjennomførte et web-basert kurs i KBP før oppstart i praksis. Deretter utarbeidet studentene en klinisk problemstilling i samarbeid med praksisfeltet, gjennomførte litteratursøk og kritisk vurdering av forskningslitteratur, utarbeidet kunnskapsoppsummering og implementeringsplan. Fremlegg med Poster i praksis. Tidsramme: To semestre mot slutten av utdanningen.

Studentene gjennomførte læringsaktiviteter ut i fra detaljerte læringsutbyttebeskrivelser i programplanen. De startet med å oppøve ferdigheter i å søke, vurdere og oppsummere kunnskapskilder. Deretter jobbet studentene med metoder for kvalitetsforbedring der de sammenlignet observert praksis med best praksis beskrevet i retningslinjer og registerdata. Det siste fokusområdet var prosjektledelse i forbedringsarbeid i praksis der studetnene utarbeidet en endringsplan, økonomisk plan og analyse.Tidsramme: Progresjon over tre år.

Studentene fikk tildelt en klinisk problemstilling fra praksisfeltet som de arbeidet med i grupper. Studentene søkte og vurderte forskningslitteratur under veiledning og utarbeidet et forslag til implementeringsplan. Fremlegg (Power-Point). Studentene utarbeidet en Poster som beskrev gruppens arbeidsprosess. Beste poster ble premiert. Alle deler av prosjektet ble vurdert og gitt graderte karakterer. Tidsramme: Mot slutten av utdanningen.

Studentene, som jobbet to og to, anvendte trinnene i KBP relatert til en oppgitt klinisk problemstilling fra praksisfeltet. Det ble inngått en kontrakt mellom student og veileder i praksisfeltet som beskrev mål og handlingspaln for prosjektet. Studentene fikk veiledning av lærer og praksisveileder. Fremlegg i praksis. Tidsramme: Ett semester mot slutten av utdanningen.

Studentene gjennomførte et KBP-prosjekt i samarbeid med kommunehelsetjenesten Studentene identifiserte et kliniske problem som var relevant for praksisfeltet og utarbeidet en implementeringsplan for praksis. Fagutvikling og lederskap var vektlagt. Fremlegg som ble vurdert og gitt gradert karakter. Tidsramme: 2-3 semestre mot slutten av utdanningen.

Artikkelen trekker frem betydningen av samarbeid med bibliotekar for å planlegge og gjennomføre undervisning om KBP. Det gis en detaljert beskrivelse for hvordan kunnskapsbaserte søk skal utføres. Søk og kritisk vurdering er utdypet spesielt. 
byttebeskrivelser $(24,27)$. Et fellestrekk var at studieoppgavene omfattet både teori- og praksisemner (19-24,26,27,29), og i tre av studiene arbeidet studentene med samme oppgave over flere semestre $(20,23,26)$. Ross m.fl. hadde en studieoppgave for hvert av trinnene i KBP (27), mens andre beskrev en studieoppgave som omfattet flere trinn $(20,24,26,28)$.

Veiledning Flere studier fremhevet betydningen av veiledning $(21,23,24,26,27,29)$. I en studie

\section{(1) anvende e-læring i kombinasjon med studieoppgaver ser ut til å gi studentene grunnleggende forståelse for KBP.}

fikk studentene veiledning fra samme lærer over to semestre fordi en studieoppgave strakte seg over flere semestre (26). Andre trakk frem lærerrollen som sentral både i veiledning og for å gi tilbakemelding på konkrete studieoppgaver (27-29). En studie (24) rapporterte at studentene $\mathrm{i}$ liten grad ble oppmuntret av praksisveiledere til å jobbe kunnskapsbasert.

Presentasjoner og vurderinger I de fleste studiene hadde studentene fremlegg med Poster eller PowerPoint i praksisfeltet (19-21,23,26-29). I en studie ble det anvendt en mal for presentasjonen for å sikre at alle trinnene i prosessen ble fulgt (26) og i fire studier ble det gitt karakter på arbeidene $(22,23,26,28)$. To artikler beskrev premiering av beste poster $(22,28)$. Studentene vurderte premiering som morsomt og sa det bidro til en sunn konkurranse mellom gruppene (28).

\section{Samarbeid mellom utdanning og praksisfelt}

I de fleste inkluderte artiklene ble samarbeidet mellom prak- sisfelt og utdanning vektlagt (19-24,26-29). I fem studier ble betydningen av at begge parter deltok i planleggingsfasen spesielt fremhevet $(21,23,26,28,29)$. Det at lærer veiledet på konkrete forbedringsprosjekter i praksisfeltet ble beskrevet som positivt $(22,23,26,28)$. Basert på en litteraturgjennomgang, antydet Moch og kollegaer (19) at prosjektsamarbeid om KBP mellom praksisfelt og utdanning kunne bidra til kompetanseheving både for studenter og ansatte $\mathrm{i}$

praksisfeltet. Et slikt samarbeid kunne, ifølge flere av artiklene, bli en vinn-vinn-situasjon for både utdanning og praksisfelt $(19,24,26)$ og derved bidra til kvalitetsforbedring i praksis (19).

Et gjennomgående trekk var at studentene jobbet med studieoppgaver som var basert på kliniske problemstillinger fra praksisfeltet (19-24,26-29). I fem artikler hadde praksisfeltet forberedt hvilke temaer studentene skulle arbeide med i praksisperioden $(21,22,26,28,29)$. Killeen og Barnfather (26) vektla at studentene fikk veiledning $\mathrm{i}$ arbeidet med å utforme en klinisk relevant problemstilling for praksisfeltet. Denne problemstillingen ble utgangspunkt for forbedringsprosjekter der studentene anvendte trinnene i KBP under veiledning. I en annen studie (29) arbeidet studentene sammen to og to med å formulere problemstilling i samarbeid med praksisveiledere. Det å formulere problemstillinger ble beskrevet som det mest utfordrende med å arbeide kunnskapsbasert $(24,26)$.

Hvem som veiledet studen- tene i KBP varierte i de inkluderte artiklene. Noen beskrev at studentene fikk regelmessig veiledning av praksisveileder $(22,28,29)$, mens andre beskrev veiledningsprosessen som et samarbeid mellom praksisveileder og lærer $(21,23,27)$. En artikkel beskrev at kompetansekravet til praksisveiledere var på masternivå og med gjennomført kurs i KBP (29). I flere studier oppga ansatte i praksisfeltet at de hadde nytte av studentenes arbeider $(22,23,26,28,29)$. Selv om arbeidene ble oppfattet som nyttige fra praksisfeltet, oppga de ansatte at det var avsatt for liten tid for å gå i dybden på de foreslåtte endringene (28). Moch og Cronje antydet at det nye studieprogrammet hvor studentene blant annet underviste om KBP og ledet kunnskapsgrupper i praksis kunne bidra til å redusere barrierene mot KBP (22).

\section{DISKUSJON}

Selv om KBP har fått betydelig oppmerksomhet både i helsetjenesten og i profesjonsutdanningene, viser denne litteraturgjennomgangen at temaet i mindre grad har vært belyst gjennom forskning. Til tross for betydelige forskjeller i kvalitet, design og metode, antyder studiene at noen fellestrekk er viktig å vektlegge ved innføring av KBP i sykepleierutdanningen.

Studiene peker i retning av at systematiske undervisningsopplegg om KBP gjennom hele utdanningen har positiv innvirkning på studentenes læring. Når alle trinnene i KBP inkluderes på en systematisk måte i programplanen, øker studentenes innsikt, holdninger og ferdigheter i KBP. Progresjon i læringsaktiviteter over flere emner ser ut til å ha betydning. En forklaring kan være at KBP fordrer et ulikt sett 
av ferdigheter som studentene trenger tid for å lære. Dersom det ikke legges opp til progresjon gjennom tre år antyder litteraturgjennomgangen at opplæring bør legges mot slutten av utdanningen. Dette kan henge sammen med at studentene da er mer sosialiserte i egen læringsprosess og har oppnådd økt forståelse for sykepleiefaglige spørsmål.

Et gjennomgående trekk i studiene er at det anvendes en kombinasjon av flere læringsmetoder. Det anbefales at studieoppgavene om KBP har et visst omfang og at det legges opp til en prosessorientert tilnærming med arbeid i grupper. Å anvende e-læring i kombinasjon med studieoppgaver ser ut til å gi studentene grunnleggende forståelse for KBP. Her i Norge har Nasjonalt kunnskapssenter for helsetjenesten et gratis e-læringskurs om KBP (30) som kan anvendes i utdanningen. Studiene tilkjennegir at undervisning om trinnene i KBP før oppstart i praksis kan bidra til kompetanseheving både for studenter og ansatte i praksisfelt.

Litteraturgjennomgangen antyder at studentene må ha mye øvelse for å oppnå tilstrekkelige ferdigheter i trinnene i KBP. Det samsvarer med funn fra studier i medisinerutdanningen $(31,32)$. Evne til refleksjon og kritisk vurdering er viktig for alle profesjonsutøvere og er helt vesentlig for kunnskapsbasert yrkesutøvelse. I de inkluderte studiene er dette grundig behandlet.

Trening i å formulere kliniske spørsmål er vektlagt i mange av artiklene og ser ut til å være av betydning. Et gjennomgående trekk er at kliniske spørsmål blir formulert enten med utgangspunkt i studentenes praksiserfaringer eller på bestilling fra praksisfeltet. Finotto og kollegaer påpeker at dette kan være en av de vanskeligste fasene i prosessen med KBP fordi det innebærer både kritisk tenkning og bruk av PICO (24).

Flere av studiene fremhever at praksisfeltet er en god arena for studentenes læring. Trepartssamarbeidet mellom lærer, studenter og sykepleiere, der KBP anvendes på konkrete kliniske problemstillinger, ser ut til å virke positivt inn på studentenes læring. Nettopp det å få til gode koblinger mellom studentenes læringsaktiviteter i høyskolen og i praksisfeltet anses som et viktig anliggende for profesjonsutdanningene $(33,34)$. Det å ta i bruk arbeidsmetoder i KBP handler om å knytte sammen kunnskap fra forskning, klinikeres erfaringer og brukerkunnskaper (4). Funnene fra denne litteraturgjennomgangen understreker at fellesskap mellom utdanning og praksisfelt er sentralt og må bygges over tid. Gjennom arbeid med konkrete praksisprosjekter lærer studentene verdien av kritisk refleksjon over praksis, og de får innsikt i forskningens betydning for yrkesutøvelsen. Samarbeidet mellom praksisveiledere og studenter i planlegging av søkestrategier og kritisk vurdering av forskningslitteratur ser ut til å bidra til økt kompetanse for begge parter. Studentenes presentasjoner i form av poster eller fremlegg i praksisfeltet får gode tilbakemeldinger og oppleves positivt.

Litteraturgjennomgangen antyder at samspillet som oppstår som følge av å implementere $\mathrm{KBP}$ som metode i praksisstudier kan ha positiv innvirkning på kvalitetsarbeid i praksis. Det ser ut til at veiledning fra lærer på praksisprosjekter bidrar til å stimulere det faglige engasjementet $i$ praksisfeltet. Studiene fremhever at ansatte i praksisfeltet har nytteverdi av de konkrete resultatene fra samarbeidsprosjektene og at resultatene kan avvendes for å forbedre praksis.

Litteraturgjennomgangen viser at KBP kan bidra til å øke studentenes innsikt i forskning. At studenter på bachelornivå får opplæring i og erfaring med å lese og kritisk vurdere forskning under utdanningen anses som positivt $(35,36)$. I Norge oppfordres utdanningsmiljøene til å legge opp studieprogrammene slik at studentene får erfaring $i$ å anvende forskning i løpet av utdanningen (37). Systematikken med trinnene i KBP kan være et godt hjelpemiddel. Det antydes videre at det å trekke inn helsefaglig bibliotekar både i utviklingen av programplanen og i undervisningen kan øke studentenes ferdigheter på feltet.

Litteraturgjennomgangen dokumenterer at det er behov for både norsk og internasjonal forskning om systematisk bruk av KBP som metode i veiledningen av sykepleiestudenter. Kunnskapsgrunnlaget på dette feltet er begrenset. Det trengs mer kunnskap om hvordan utdanningene implementerer undervisning om KBP i utdanningen, hvilke faktorer som fremmer og hemmer studentenes læring, samt større kontrollerte studier som undersøker effekten av strukturerte og målrettede opplæringstilbud i sykepleierutdanningen. Eksisterende forskning trekker frem at forpliktende samarbeid mellom utdanning og praksisfelt er avgjørende. Det anbefales læringsmetoder som tar utgangspunkt i kliniske problemstillinger der studentene gjennom studentaktive metoder i grupper tilegner seg kunnskap og ferdigheter $\mathrm{i}$ alle trinnene KBP. Videre anbefales det at læringsaktivitetene legges både til praksis og teoretiske emner. 


\section{Studiens begrensning}

De inkluderte studiene er små med betydelige forskjeller i kvalitet, design og metode. En mulig svakhet ved denne litteraturgjennomgangen er at vi ikke benyttet søkeordene «Evidence-informed practice», «evidence-informed decisionmaking» og «evidencebased health care» og at vi spisset søkene i Medline med «facilitat"» og «implement"». Dette kan ha medført at vi kan ha gått glipp av noen studier.

\section{KONKLUSJON}

Norsk og internasjonal forskning på undervisningsopplegg om KBP i sykepleierutdanningen er begrenset. Tilgjengelig forskningslitteratur antyder at en systematisk opplæring i KBP med interaktive læringsstrategier i samarbeid med praksis kan ha positiv betydning for studentenes læring. Det er behov for mer forskning som belyser ulike spørsmål og med dertil ulike design for å øke kunnskapsgrunnlaget.

\section{REFERANSER}

1. Stortingsmelding 10 (2012-2013). God kvalitet - trygge tjenester. Helse og omsorgsdepartementet. Oslo 2012.

2. Meld. St. 11 (2014-2015). Kvalitet og pasientsikkerhet 2013. Helse- og omsorgsdepartementet. Oslo 2014.

3. Helse og omsorgsdepartementet. HelseOmsorg21. Et kunnskapssystem for bedre folkehelse. Regjeringen.no 2014.

4. Nortvedt M, Jamtvedt G, Nordheim LV, Reiner LM. Jobb kunnskapsbaseret! 2. utgave ed. Oslo: Akribe; 2012.

5. Dawes M, Summerskill W, Glasziou P, Cartabellotta A, Martin J, Hopayian K, et al. Sicily statement on evidence-based practice. BMC Med Educ. 2005;5(1):1. 6. Melnyk BM, Fineout-Overholt E. Evidence-based practice in nursing \& healthcare: A guide to best practice: Lippincott Williams \& Wilkins; 2011.

7. Pravikoff DS, Tanner AB, Pierce ST. Readiness of US Nurses for EvidenceBased Practice: Many don't understand or value research and have had little or no training to help them find evidence on which to base their practice. AJN The American Journal of Nursing. 2005;105(9):40-51.
8. Ciliska D. Educating for EvidenceBased Practice. Journal of Professional Nursing. 2005;21(6):345-50.

9. Smith-Strøm H, Oterhals K, Rustad EC, Larsen T. Culture crash regarding nursing students' experience of implementation of EBP in clinical practice. 2012. 10. Sandvik G, Stokke K, Nortvedt M. Hvilke strategier er effektive ved implementering av kunnskapsbasert praksis i sykehus. Sykepleien Forskning. 2011;6(2):160-7.

11. Meld. St. 13 (2012-2013). Utdanning for velferd. Samspill i praksis.: Kunnskapsdepartementet, editor. 2012.

12. Young T, Rohwer A, Volmink J, Clarke M. What are the effects of teaching evidence-based health care (EBHC)? Overview of systematic reviews. PloS one. 2014;9(1).

13. Glasziou P, Burls A, Gilbert R. Evidence based medicine and the medical curriculum. Bmj. 2008;337.

14. Maggio LA, Tannery NH, Chen HC, ten Cate 0, O'Brien B. Evidence-based medicine training in undergraduate medical education: a review and critique of the literature published 2006-2011. Academic Medicine. 2013;88(7):1022-8.

15. Florin J, Ehrenberg A, Wallin L, Gustavsson P. Educational support for research utilization and capability beliefs regarding evidence-based practice skills: a national survey of senior nursing students. Journal Of Advanced Nursing. 2012;68(4):888-97.

16. Database for statistikk om høgre utdanning NSD. Publikasjoner 2015.

17. Arksey H, $\mathrm{>}$ Malley L. Scoping studies: towards a methodological framework. International journal of social research methodology. 2005;8(1):19-32.

18. French B. Contextual factors influencing research use in nursing. Worldviews on Evidence-Based Nursing. 2005;2(4):172-83.

19. Moch SD, Cronje RJ, Branson J. Part 1. Undergraduate nursing evidence-based practice education: envisioning the role of students. Journal of Professional Nursing. 2010;26(1):5-13.

20. Kim SC, Brown CE, Fields W, Stichler JF. Evidence-based practice-focused interactive teaching strategy: a controlled study. Journal of advanced nursing. 2009;65(6):1218-27.

21. Zhang Q, Zeng T, Chen Y, Li X. Assisting undergraduate nursing students to learn evidence-based practice through self-directed learning and workshop strategies during clinical practicum. Nurse education today. 2012;32(5):570-5.

22. Moch SD, Cronje RJ. Part II. Empowering grassroots evidence-based practice: a curricular model to foster undergraduate student-enabled practice change. Journal of Professional Nursing. 2010;26(1):14-22.
23. Kruszewski A, Brough E, Killeen MB. Collaborative strategies for teaching evidence-based practice in accelerated second-degree programs. The Journal of nursing education. 2009;48(6):340-2.

24. Finotto S, Carpanoni M, Turroni EC, Camellini R, Mecugni D. Teaching evidence-based practice: developing a curriculum model to foster evidencebased practice in undergraduate student nurses. Nurse education in practice. 2013;13(5):459-65.

25. Klem ML, Weiss PM. Evidence-based resources and the role of librarians in developing evidence-based practice curricula. Journal of professional Nursing. 2005;21(6):380-7.

26. Killeen MB, Barnfather JS. A Successful Teaching Strategy for Applying Evidence-based Practice. Nurse Educator. 2005;30(3):127-32.

27. Ross AM, Noone J, Luce LL, Sideras SA. Spiraling evidence-based practice and outcomes management concepts in an undergraduate curriculum: a systematic approach. The Journal of nursing education. 2009;48(6):319-26.

28. Schmidt NA, Brown JM. Use of the innovation-decision process teaching strategy to promote evidence-based practice. Journal of Professional Nursing. 2007;23(3):150-6.

29. Brancato VC. An innovative clinical practicum to teach evidencebased practice. Nurse Educator. 2006;31(5):195-9.

30. Nasjonalt kunnskapssenter for helsetjenesten. 2015.

31. Johnston JM, Schooling CM, Leung GM. A randomised-controlled trial of two educational modes for undergraduate evidence-based medicine learning in Asia. BMC Medical Education. 2009;9:63. 32. Bradley P, Oterholt C, Herrin J, Nordheim L, Bjørndal A. Comparison of directed and self-directed learning in evidence-based medicine: a randomised controlled trial. Medical Education. 2005;39(10):1027-35.

33. Benner P, Heggen K, Thorbjørnsen KM, Kjerland L. Å utdanne sykepleiere: behov for radikale endringer. [Oslo]: Akribe; 2010. 277 s. p.

34. Molander A, Terum LI, editors. Profesjonsstudier. Oslo: Universitetsforlaget; 2008.

35. Boyer E. The Boyer commission on educating undergraduates in the research university, reinventing undergraduate education: A blueprint for America's research universities. Stony Brook, NY. 1998.

36. Healey M, Jenkins A. Developing undergraduate research and inquiry: Higher Education Academy York; 2009. 37. Universitets- og høyskolerådet. Utdanning+FoU=Sant. 2010. 